Market and Competition Law Review / VOLUME II / No. 1 / APRIL 2018

\title{
Challenges and Constraints to Recognition in the Field of Freedom of Circulation: The Relevance of the Fraus Legis Institute in European Union Law
}

Dulce Lopes**

\begin{abstract}
The relevance of fraus legis - a falsely presented state of affairs - both in internal and private international law, and particularly within recognition procedures, has not been undisputed throughout the years. And in the midst of integration or close cooperation arrangements it might seem that the institute of fraus legis would definitively lose its interest due to an "unshaken" mutual confidence in the activity of other public authorities.

This is however not the case, as demonstrated by European Union law where both legislative and case law examples show the renewed importance of such truthfulness or veracity requirement.

Bearing this is mind, the present article has a dual purpose: the first aims to describe the legal concept of recognition in its diversity and richness. As an aggregating factor we will subsequently turn our attention to the "internal structure" of that concept and to the conditions or requisites it is dependent upon. One of such conditions is precisely the control of veracity of the act or situation that aims to be recognised by the receiving State.
\end{abstract}

KEYWORDS: fraus legis, migration, freedom of movement, recognition

\footnotetext{
* Date of Reception: 03 January 2018. Date of Acceptance: 05 January 2018.

** Professor at the University of Coimbra, Faculty of Law, 3004-528, Coimbra, Portugal, dulce. rdgr@gmail.com.
} 


\section{Introductory remarks}

Within integration or close cooperation arrangements, where trust plays a pivotal role, it would seem that fraus legis or evasion of laws would lose its interest as a mechanism of control in recognition procedures.

This is however not the case, as demonstrated by European Union law where both legislative and case law examples show the renewed importance of such requirement.

In fact, the European Court of Justice has highlighted in several occasions that Member States have the choice not to draw effects from acts issued by or activities that took place in other Member States, if obtained fraudulently. This has been asserted in traditional situations of acquisition of nationality, convenience marriages and the fulfilment of residence criteria for attainment of residence titles.

Access to professional activities and, mainly, the attribution of driving licences have also attracted the attention of the Court, which has consistently upheld the relevance of fraus legis in cases where artificial, untrue or non-serious situations are created and used in order to attain rights and benefits awarded or permitted by European Union law.

Our aim is to track the evolution of both the recognition mechanism and the fraus legis requirement, explaining its particular importance as a mechanism that allows for a more rooted mutual trust between Member States, constituting, therefore, an exception to recognition in hard cases. This article will also analyse the difficulty of defining clear guiding lines and procedures for the correct control (detection and proof) of a fraudulent situation and the effects that can be drawn from such cases.

The ultimate purpose is to cast a fresher glance towards the traditional foundations of the recognition mechanism and the fraus legis doctrine and to bring them closer together, taking into consideration the new challenges that Member States face while trying to effectively implement European Union law.

\section{Recognition as an essential tool for the internal market}

It seems almost a redundancy to recall the influence that recognition - in particular mutual recognition - has had on the development of the internal market and its fundamental freedoms by rendering easier, faster and less burdensome the circulation of goods, persons, services and capital. Also in the area of freedom, security and justice, recognition has been a landmark for the development of instruments that allow for a closer Union, with more effective tools and instruments. 
However, the wave of recognition has always had its critics and has shown some flaws in some cases, even systemic ones. ${ }^{1}$ A more structured approach to the institute of recognition, its multiple shapes and foundational criteria are, thus, presented henceforth.

\subsection{Concept of recognition}

As an instrument of relationship between legal orders, recognition has been profusely used in the international arena, either in public international law (as happens with the recognition of States, governments, international organizations, etc.), in private international law (recognition of judicial and arbitral decisions, authentic acts ${ }^{2}$ and private situations) and in the more recent field of international administrative $\operatorname{law}^{3}$ (recognition of administrative acts and administrative situations).

\footnotetext{
${ }^{1}$ In the context of the application of Regulation 604/2013 (the Dublin Regulation), the Court of Justice ruled that mutual trust and recognition are subject to limitations, whenever deficiencies in the asylum procedure and detention conditions in Member States are serious (vide Judgment of 21 December 2011, N.S. V. Sec'y of State for the Home Dep't, Joined cases C-411/10 \& C-493/10, EU:C:2011:865; Judgment of 14 November 2013, Bundesrepublik Deutschland v. Kaveh Puid, C-4/11, EU:C:2013:740; Judgment of 10 December 2013, Shamso Abdullahi v. Bundesasylamt, C-394/12, EU:C:2013:813). The same has been decided within the mechanism of the European Arrest Warrant in the European Court of Justice Judgment of 5 April 2016, Pál Aranyosi and Robert Căldăraru, Joined cases C-404/15 and C-659/15 PPU, EU:C:2016:198.

${ }^{2}$ In this specific area, Regulation (EU) No. 650/2012 of the European Parliament and of the Council of 4 July 2012 on jurisdiction, applicable law, recognition and enforcement of decisions and acceptance and enforcement of authentic instruments in matters of succession and on the creation of a European Certificate of Succession has changed the legal framework regarding authentic instruments from recognition to acceptance, as a way to harmonise their evidentiary effect [Carmen Azcárraga Monzonís, "New developments in the scope of the circulation of public documents in the European Union", Zeitschrift für Zivilprozess International - Jahrbuch des Internationalen Zivilprozessrechts, 18 (2013) 256] and to better differentiate between the instrumentum and the negotium it embodies.

${ }^{3}$ Lorenz von Stein, "Einige Bemerkungen über das internationale Verwaltungsrecht", Jahrbuch für Gesetzgebung, Verwaltung und Volkswirtschaft im Deutschen Reich, 6 (1882): 395-442, has been credited as the first representative of this field, according to Christian Tietje, "Internationalisiertes Verwaltungshandeln", Rechtstheorie 39 (2008): 258-263.

Among authors that aimed over the years to characterise international administrative law, either by bringing it closer together to an international law paradigm, or by seeing it as a new national law subject (analogous to private international law), a special reference is due to Neumeyer, who established the necessity of such field in imperatives of justice, demanding that internal border rules ("Grenznorm") recognise foreign rules and decisions [Karl Neumeyer, Internationales Verwaltungsrecht - Allgemeiner Teil, Vol. IV (Zürich, Leipzig: Verlag für Recht und Gesellschaft AG, 1936), 19-23 and 436-438].

The search for an identity for international administrative law is no easy task due to its plurality of areas and methods of intervention [vide Eberhard Schmidt-Aßmann, "Verfassungsprinzipien
} 
In general, recognition, in its variations, integrates a legal proposition ${ }^{4}$ that allows for the production of effects of a foreign act or situation in the receiving State. This reception, however, does not correspond to a "blank check" towards the State of origin, since it is essential to the figure of recognition that the ad quem State preserves a certain margin of control over the criteria and effects of such recognition.

As Moura Vicente puts it, the figure of recognition involves a waiver to primarily regulate the situation at hand, ${ }^{5}$ but not to control its effects in the recognising State. ${ }^{6}$ Therefore, there is no definitive waiver or transfer of sovereignty or public power to the State of origin, ${ }^{7}$ but a balancing of interests between legal orders and the individual interests affected, according to Wenander. ${ }^{8}$

This control is not impeded by the circumstance that, in a relevant number of situations, recognition has become more and more automatic and guaranteed in general terms and therefore does not depend upon a concrete recognition act. In any case, the State reserves a faculty of control of the basic premises of recognition, even when it is prima facie construed as mandatory.

für den Verwaltungsverbund", in Grundlagen des Verwaltungsrechts, Vol. I, $2^{\text {nd }}$ ed., ed. HoffmannRiem, Schmidt-Aßmann, Voßkuhle (München: Verlag C. H. Beck, 2012), 299]. In any case, conceived as a discipline that regulates administrative situations in an international setting, it necessarily includes the area of recognition of foreign administrative acts that is essential for our study. ${ }^{4}$ Term used by Dominique Bureau and Horatia Muir Watt, Droit International Privé, Tome I Partie Générale, $3^{\text {rd }}$ ed. (Paris: Presses Universitaires de France, 2014), 274, within recognition of court decisions.

${ }^{5}$ Dário Moura Vicente, "Liberdades comunitárias e direito internacional privado", Revista da Ordem dos Advogados 69 (2009): 808.

${ }^{6}$ Paulo Otero, "Normas administrativas de conflitos: As situações jurídico-administrativas transnacionais", in Estudos em Memória do Professor Doutor António Marques dos Santos, Vol. II, ed. Dário Moura Vicente, Luís de Lima Pinheiro, Jorge Miranda (Coimbra: Almedina, 2005) 786-787, mentions a retraction or amputation of the territorial competence of national administrative law in favour of a better positioned foreign law, but which cannot lead to an integral and therefore unconstitutional abdication of national law.

${ }^{7}$ As seems to be the position of Stefan Burbaum, Rechtsschutz gegen transnationales Verwaltungshandeln (Baden-Baden: Nomos Verlagsgesellschaft, 2003), 27 and Krysztof Wojtyczek, "L'ouverture de l'ordre juridique de l'État aux actes de puissance publique étrangers (l'exemple des instruments de l'Union Européenne en matiére d'immigration)", European Review of Public Law 21, 1 (2009), 115.

${ }^{8}$ Henrick Wenander, "Recognition of foreign administrative decisions - balancing international cooperation, national self-determination, and individual rights", Zeitschrift für ausländisches öffentliches Recht und Völkerrecht 71 (2011), 756. 
We do not adhere, therefore, to the position according to which when no specific reception act has been adopted, the concept of recognition can be merely used in an imprecise manner. ${ }^{9}$ Our position is rather opposite, since it values the control possibilities and review instruments of the State of destiny that are inherently multiform and flexible.

This does not mean we ignore that most doctrinal developments have been centred in the qualification of the "recognition act", either by viewing it as a condictio iuris ${ }^{10}$ or an accessory decision ${ }^{11}$ which would allow for the extension of effects of a foreign act, or by qualifying it as a constitutive decision which created a new nationalised (substitutive) situation based on the data provided by the foreign act. ${ }^{12}$

Between these two ends, a third proposal upholds that both States (of origin and recognition) determine the effects of recognition together, ${ }^{13}$ in a way that the recognition rule is a complex norm resulting from a collaborative effort between the lex auctoris and the lex fori. ${ }^{14}$

\footnotetext{
${ }^{9}$ As do Hans Christian Röhl, "Conformity assessment in European product safety law", in The European Composite Administration, ed. Oswald Jansen and Bettina Schöndorf-Haubold (Cambridge: Intersentia, 2011), 214; and Volkmar Götz, "Der Grundsatz der gegenseitigen Anerkennung im europäischen Binnenmarkt”, in Liber Amicorum Günther Jaenicke - Zum 85. Geburtstag, ed. Volkmar Götz, Peter Selmer and Rüdiger Wolfrum (Berlin: Springer, 1998), 778.

${ }^{10}$ According, among others, to Prosper Fedozzi, "De l'efficacité extraterritoriale des lois et des actes de droit public", Recueil des Cours, Volume 27 - II (1929)183, and Werner Meng, "Recognition of foreign legislative and administrative acts", in Encyclopaedia of Public International Law, Vol. IV, ed. Rudolf Berhnardt (Amsterdam, North-Holland: Elsevier, 1992), 51.

${ }^{11}$ Eberhard Schmidt-Aßman, "Internationalisation of administrative law: Actors, fields and techniques of internationalisation - impact of international law on national administrative law", Revue Européenne de Droit Public 18, 1 (2006) 260.

${ }^{12}$ As do Giuseppe Biscottini, Diritto Amministrativo Internazionale - Tomo Primo/ La Rilevanza degli Atti Amministrativi Stranieri (Padova: CEDAM, 1964), 118 and 120, and Klaus Vogel, Der räumliche Anwendungsbereich der Verwaltungsrechtsnorm - Eine Untersuchung über die Grundfragen des sog. internationalen Verwaltungs- und Steuerrechts (Frankfurt am Main: Alfred Metzner Verlag, 1965), 323-337.

${ }^{13}$ Käte Weiß, Die Anerkennung ausländischer Verwaltungsakte (Göttingen: Buchdruckerei W. Flentje, 1932), 56.

${ }^{14}$ Charalambos Pamboukis, L’Acte Public Étranger en Droit International Privé (Paris: L.G.D.J., 1993), 151. Already J.-P. Niboyet, Cours de Droit International Privé (Paris: Librairie du Recueil Sirey, 1949), 671, conceived exequatur as a mixture between production of effects of previous rights and new ones, since it shapes and changes their content. Also Ernst Frankenstein, Internationales Privatrecht (Grenzrecht), Vol. I (Berlin-Grunewald: Dr. Walter Rothschild, 1926), 328 and 343, understood recognition as an a posteriori control, because it is occupied with only part of the history of the act, looking at it from the point of view of the State of destiny.
} 
Given the new and ever changing phenomenology of recognition, this proposal sets the correct framework for a wide range of control instruments available to the State of destiny, both prior (recognition acts, declarations, certifications) or subsequent (revocations, suspensions, prohibitions) to recognition. ${ }^{15}$

The institute of recognition is therefore, in its essence, a control procedure that links the issuing State and the receiving State in a wide variety of forms, leaving, in any case, a relative autonomy to the receiving State, since it must be allowed to adopt its own criteria for recognition. Yet, it should be mentioned that these criteria do not necessarily correspond to the ones laid down by the State of origin while actively issuing the act to be recognised. ${ }^{16}$

\subsection{Types of recognition}

Although the phenomenon of mutual recognition developed under the umbrella of the European Union has attracted most of the international attention, there are several other forms of welcoming acts that have the propensity to produce effects "outside their doors".

In order to convey the complexity of this institute, several analyses can be produced using different looking lenses.

$i$. If one looks at the internal structure of recognition, we might distinguish between an integrated recognition, which occurs regarding acts that have an external origin (issued for instance by entities in charge of territorial administration of States or by Institutions or organs of the European Union) but perform a necessarily internal function (they are

\footnotetext{
${ }^{15}$ Within the European Union, Mansel rightfully considers that at a primary law level there is no rule that indicates a single or preferred way to recognise, leaving the choice regarding the concrete method of recognition up to the Member States [Heinz-Peter Mansel, "Anerkennung als Grundprinzip des Europäischen Rechtsraums - Zur Herausbildung eines europäischen Anerkennungs-Kollisionsrechts: Anerkennung statt Verweisung als neues Strukturprinzip des Europäischen internationalen Privatrechts?", Rabels Zeitschrift für ausländisches und internationales Privatrecht 70, 4 (2006), 681-682].

${ }^{16}$ This allows us to distance ourselves from the positions that link recognition and the State of origin rule, viewing it as an occult or implicit rule of conflict. In fact, recognition supposes a flexible mix between States of origin and destination, contrary to a strict conflict of law perspective. Also adopting this view, vide, among others, Afonso Patrão, Autonomia Conflitual na Hipoteca e Reforço da Cooperação Internacional: Removendo Obstáculos ao Mercado Europeu de Garantias Imobiliárias (Lisboa: Livros Horizonte, 2017), 433-449.
} 
directly addressed to one or several individuals); ${ }^{17}$ a mutual recognition, which takes place in spaces of horizontal cooperation between States (the European Union, and to a much lower extent, the Mercosul and other bilateral or multilateral arrangements) and in which, as a rule, the extension of effects of a transnational or transterritorial act is ensured by other participant States; and a unilateral recognition, where recognition of foreign acts is merely eventual and dependent upon the willingness of the recognising State. ${ }^{18}$

ii. Changing the light of our analysis and focusing on the techniques of recognition, distinctions can also be made between a unilateral recognition, which results from a unidirectional decision of the recognising State, and a mutual recognition, seen as a manifestation of a consensual or cosmopolitan extraterritoriality. ${ }^{19}$ Recognition can, moreover, be automatic

${ }^{17}$ It is discussed whether this situation should be included in the scope of recognition, or if another legal terminology should be preferred, such as reception or incorporation. Given the open notion of recognition that consists in attributing internal legal relevance to external acts [according to Luís de Lima Pinheiro, "Reconhecimento autónomo de decisões estrangeiras e controlo do direito aplicável”, in Estudos de Direito Internacional Privado - Direito de Conflitos, Competência Internacional e Reconhecimento de Decisões Estrangeiras (Coimbra: Almedina, 2006), 436], we believe this is the best explanatory framework. Also Nicola Bassi, Mutuo Riconoscimento e Tutela Giurisdizionale - La Circolazione degli Effeti del Provvedimento Amministrativo Straniero fra Diritto Europeo e Protezione degli Interessi del Terzo (Milano: Giuffrè Editore, 2008), 48-68, distinguishes between a centralised mutual recognition (of community acts) and decentralised mutual recognition (of transnational acts).

${ }^{18}$ For a study of these types of recognition, vide our Eficácia, Reconhecimento e Execução de Actos Administrativos Estrangeiros (Coimbra: Almedina, 2018), in print.

${ }^{19}$ Kalypso Nicolaidis and Gregory Shaffer, “Transnational mutual recognition regimes: Governance without global government”, Law and Contemporary Problems 68, Summer-Autumn (2005): 267. In another article, Kalypso Nicolaïdis perceives unilateral recognition as an ad hoc, partial and arbitrary instrument [Kalypso Nicolaïdis, "Globalization with human faces: Managed mutual recognition and the free movement of professionals", in The Principle of Mutual Recognition in the European Integration Process, ed. Fiorella Kostoris and Padoa Schioppa (Hampshire: Palgrave Macmillan, 2005), 132]. Nevertheless, unilateral recognition is not necessarily erratic. Not only is it frameworked by some international instruments and legal doctrine, but also subject to national regulation which increasingly tends to impose a more adequate composition of interests that might, in relevant cases, point towards recognition.

Also mutual recognition has its critics. Some use the same arguments employed against unilateral recognition: mainly that it is hard to define mutually recognised in general terms [Kenneth A. Armstrong, "Mutual recognition", in The Law of the Single European Market - Unpacking the Premises, ed. Catherine Barnard and Joanne Scott (Oxford: Hart Publishing, 2002), 230]. Others consider that its automatic nature endangers the protection of human rights, which still hold a significant national dimension [Laurence Sinopoli, "Une épreuve pour les droits de l'Homme - de l'universel postulé à la mondialisation réalisée?”, in Justices et Droit du Procès - Du Légalisme Procédural à L'Humanisme Processuel - Mélanges en L'Honneur de Serge Guinchard (Paris: Dalloz, 
or conditional. These two modes of recognition are not totally opposed, ${ }^{20}$ since the control task inherent to the institute of recognition can be reflected in a gradual set of requisites, rendering it difficult to segment the ones that are purely automatic from the ones that imply a certain level of mediation from the recognising State.

Indeed, in some cases, conditional recognition is accompanied by important facilitation mechanisms, ${ }^{21}$ while in others automatic recognition is complemented by formal obligations of registration, communications or declarations from the interested parties. ${ }^{22}$ As to the better option between automatic and conditional recognition, there is also no straight line, despite the fact that a long-standing trend within the European Union prefers the former to the latter. In fact, establishing some form of conditional recognition can allow for a wider range of accepted legal consequences in the destination State, as the Court of Justice of the European Union has already decided, by refusing to recognise the same effects to situations where a professional uses the title from the State of origin and not the title of the State of destination (or an equivalent one). ${ }^{23}$

\footnotetext{
2010), 369-379], while others see it as a dishonest and unpredictable system that can be used as a dangerous toy by European Union authorities [Gareth Davies, "Is mutual recognition an alternative to harmonization? Lessons on trade and tolerance of diversity from the EU", in Regional Trade Agreements and the WTO Legal System, ed. Lorand Bartels and Federico Ortino (Oxford: Oxford University Law, 2006), 273-275].

${ }^{20}$ Contrariwise, Miguel Prata Roque, A Dimensão Transnacional do Direito Administrativo - Uma Visão Cosmopolita das Situações Jurídico-Administrativas (Lisboa: AAFDL, 2014), 1210 and 12171219.

${ }^{21}$ There are situations where recognition is dependent upon the issuing of a formal authorisation, but in this procedure strong automatisms intervene. For instance, Regulation (CE) no. 1107/2009 of the European Parliament and of the Council of 21 October 2009 concerning the placing of plant protection products on the market allows for the use of an authorisation of reference issued by another State in a comparable situation as an evidentiary basis for the national decision (article 40). ${ }^{22}$ Directive 2006/123/EC of the European Parliament and of the Council of 12 December 2006 on services in the internal market establishes a very strict framework for the admission of authorisation schemes, but allows for the use of less restrictive means, such as declarations of providing a service or performing an activity.

${ }^{23}$ Cfr. Judgment of 7 November 2000, Grand Duchy of Luxemburg v. European Parliament and Council of the European Union, C-168/98, EU:C:2000:598. For a framework of these possibilities, cf. Nuno Piçarra, "A liberdade de circulação dos advogados na União Europeia - Da metamorfose da regra do tratamento nacional à extensão a nacionais de países terceiros", in Estudos em Homenagem ao Prof. Doutor Sérvulo Correia, Vol. IV, ed. Jorge Miranda (Coimbra: Coimbra Editora, 2010), 734-740.
} 
iii. Taking a closer look at the possible effects of recognition, although the most relevant ones promote fundamental freedoms and other legal situations, having therefore a positive influence in the position of individuals within the internal market and the area of freedom, security and justice, others have limitative or negative consequences by impeding or curtailing the liberties sought by individuals. ${ }^{24}$ Of course this second type of recognition is much harder to establish and to execute, since the effects linked to it demand a higher level of mutual trust and the furthering of stricter equivalence mechanisms. ${ }^{25}$

iv. Regarding the dynamism of recognition techniques, there is a certain dosage of interchange ability that accompanies the mutability of acts subject to recognition. Undeniably, the qualification of a transnational act does not correspond to the "nature of things", ${ }^{26}$ but to an option that can evolve in time and space. And experience shows that there are types of acts that are being progressively centralised (in areas that demand a uniform application of European Union law or that require a prompt response to common challenges or crises), ${ }^{27}$ while others are no longer being perceived

\footnotetext{
${ }^{24}$ Markus Möstl, "Preconditions and limits of mutual recognition", Common Market Law Review 47 (2010): 409.

${ }^{25}$ As is the case of Council Directive 2001/40/EC of 28 May 2001 on the mutual recognition of decisions on the expulsion of third country nationals, and of Council Framework Decision 2005/214/ JHA of 24 February 2005 on the application of the principle of mutual recognition to financial penalties.

${ }^{26}$ Bernhard Raschauer, “Transnationale Verwaltungsakte”, in Demokratie und sozialer Rechtsstaat in Europa: Festschrift für Theo Öhlinger, ed. Stefan Hammer, et al. (Wien: WUV Universitätsverlag, 2004), 666.

${ }^{27}$ Only as an example, Council Directive 65/65/EEC of 26 January 1965 on the approximation of provisions laid down by Law, Regulation or Administrative Action relating to proprietary medicinal products established common rules but did not confer any transnational effects to State decisions (article 3). This Directive was superseded by Directive 2001/83/EC of the European Parliament and of the Council of 6 November 2001 on the Community code relating to medicinal products for human use - which establishes transnational acts subject to mutual recognition (articles 18 and $27 \mathrm{ff}$.) and, in case of disagreement between States, leads to a single community decision (articles 32 and 121) - and by Regulation (EC) No. 726/2004 of the European Parliament and of the Council of 31 March 2004 laying down Community procedures for the authorisation and supervision of medicinal products for human and veterinary use and establishing a European Medicines Agency, which institutes an initial community decision for medications that involve wider risks and caution. On a similar note, Luca de Lucia, "Administrative pluralism, horizontal cooperation and transnational administrative acts", Review of European Administrative Law 5, 2 (2012): 43-44, concludes that the subsidiarity principle has been abandoned in favour of a centralisation wave, but expects this not to lead to indiscriminate concessions to a centralist logic.
} 
as having transnational effects, but merely as foreign acts subject to unilateral recognition. ${ }^{28}$

As a consequence, Mayer questions whether there is enough unity in diversity to talk about a single recognition method, or the preferred designation should be plural and open ended. ${ }^{29}$ From our point of view, a structured approach to recognition should be based foremost on the criteria that constitute the core of the control competences retained by the recognising State. It is through the adequate comprehension and application of such requirements that it is possible to assert the autonomy and relevance of the recognition mechanism, despite its nuanced nature.

\subsection{Criteria for recognition}

Recognition is subject to the fulfilment of several conditions that embody the control task allowing for extraterritorial effects of foreign acts. As already stated, States do not just accept decisions that are presented to them, even if they are bond to mutual recognition demands, since competent authorities must monitor whether certain requirements are met for recognition to take place.

Those conditions have been widely discussed in specialised doctrine, mostly within private international law, and can be summarised as follows: acts should be authentic and stable, issued by a competent authority, and to some extent be equivalent to the recognising State's rules. Also requirements such as the respect for the State's public order and the warranty of reciprocity play an important role in guaranteeing recognition.

Although these are the typical criteria for recognition, not all of them intervene formally and in the same way. Also not all of them are perceived to incorporate the same legal demands.

Depending on the type of recognition, these conditions can function as positive or negative criteria. In the first case they intervene $a$ priori and justify a recognition measure; in the second case they are used a posteriori

\footnotetext{
${ }^{28}$ This happens not only as a consequence of the retraction of cooperation and integration phenomena (such as Brexit), but also as an interpretation of existing institutes. Such was the case of Judgment of 7 March 2017, X and X v. État belge, C-638/16 PPU, EU:C:2017:173, in which the European Court of Justice held that visas with limited territorial validity made on humanitarian grounds fall only within national and not community law.

${ }^{29}$ Pierre Mayer, "Les méthodes de la reconnaissance en droit international privé", in Le Droit International Privé: Esprit et Méthodes - Mélanges en l'Honneur de Paul Lagarde (Paris: Dalloz, 2005), 549.
} 
as means to oppose a recognition that is undergoing or that already took place.

Also those requisites may deserve differentiated interpretation and application according to each case. And although Gautier refers to the refusal of recognition as an exceptional scenario, applying the Latin aphorism exceptio est strictissimae interpretationis", ${ }^{30}$ this is only true when there is an obligation or, at least, a prudential duty that points to recognition.

Furthermore, they may intervene with different intensities and effects, according to the situations to be recognised. For instance, the reciprocity requisite may favour recognition if it is deemed fulfilled in certain spheres (such as the internal market) or regarding specific States, or it may impede or limit recognition, if it ought to be demonstrated on a case-by-case basis. The same happens with the equivalence requisite which, according to the matter at hand and the mutual trust achieved, can incorporate several layers: from a presupposed or presumed fulfilment of equivalence standards, to the definition of minimum harmonisation rules or even to the demand of proof of tangible equivalence criteria. ${ }^{31}$

\section{The role of fraus legis within the method of recognition}

Notwithstanding the importance of the outlined criteria, it is fraus legis that deserves our fullest attention. Not only is it the core of the present article, but also its status as a requisite for recognition has not always been undisputed.

This criterion of veracity of truthfulness is, for the purpose of our analysis, of a substantive nature and should not, therefore, be confused with the mere lack of formal authenticity of the act that aims to be recognised. ${ }^{32}$ In particular, the controverted issue resides in the following: whether the attestation of artificious, unreal or feigned situations that were constituted

\footnotetext{
${ }^{30}$ Pierre-Yves Gautier, "La contrariété à l'ordre public d'une décision étrangère, échec à sa reconnaissance ou son exequatur", in Vers de Nouveaux Équilibres entre Ordres Juridiques - Liber Amicorum Hélène Gaudemet-Tallon (Paris: Dalloz, 2008), 439.

${ }^{31}$ There is also migration between these levels of demand as shown in the recent COM(2015) 550 final (Upgrading the Single Market: more opportunities for people and business), where an action plan to increase awareness of the mutual recognition principle and to revise the mutual recognition regulation (Regulation (EC) No 764/2008] is laid down, mostly due to the subsistence and increase of national regulations and practices that continue to create barriers to trade.

${ }^{32}$ Nevertheless, situations of fraud can also be mishmashed with, for instance, false declarations and identity usurpation, according to Isabelle Guyon-Renard, "La fraude en matière de l'État civil dans les États Membres de la CIEC”, Revue Critique de Droit International Privé 85, 3 (1996): 542-545.
} 
in fraus legis is a sound basis for recognition, or, on the opposite, if the demonstration of fraudulent behaviour hinders this result.

\subsection{Fraus legis in international law}

Fraus legis is a legal institute included in the general theory of law; however, since its relevance increases according to the difference of values between the rule that is set aside and the one that is artificially applied, its application is less frequent within the same legal order. ${ }^{33}$

To Lebre de Freitas, fraus legis consists on the manipulation of the constitutive facts of the Tatbestand of a norm in order to create the appearance of a legal protection that is, in concrete, inexistent. And if within internal law there are those who consider that such institute is a duplication of other violations of law, this does not occur, according to the author, within private international law. ${ }^{34}$

But even in this realm, the relevance of fraus legis has been debated, mainly because it can be regarded as illogical (given the fact that conflict of laws allows for the change of the connecting factor and, therefore, of the chosen law, offering a legal leeway to the parties), and not operational enough (since there are difficulties in determining the defrauded law, in proving the occurrence of defrauding activity and intent, and in defining the consequences of such occurrence). ${ }^{35}$

In any case, what is censored by fraus legis is the illicit character of the finality ${ }^{36}$ behind the manipulation or modification of the relevant connecting factor, either for the designation of foreign law (conflict of laws), or for the designation of the competent court (conflict of jurisdictions). ${ }^{37}$ This usually in connection with the institute of recognition, since the ultimate

\footnotetext{
${ }^{33}$ According to Gerhard Kegel and Klaus Schurig, Internationales Privatrecht - Ein Studienbuch, $9^{\text {th }}$ ed., (München: Verlag C.H. Beck, 2004), 477. Also J. P. Niboyet, "La fraude à la loi en droit international privé", Revue de Droit International et de Legislation Comparé (1926): 486, defended that fraus legis (in opposition to fraud against third parties interests) was particularly important in the private international law realm.

${ }^{34}$ José Lebre de Freitas, "A fraude à lei na provocação da competência do tribunal estrangeiro", Revista da Faculdade de Direito da Universidade de Lisboa XXXIX, 1 (1998): 12.

${ }^{35}$ For a synthesis of these criticisms, vide João Baptista Machado, Lições de Direito Internacional Privado, $3^{\text {rd }}$ ed. (Coimbra: Almedina, 1995), 276-278. Defending that fraus legis has, therefore, a limited scope in private international law, vide P. Arminjon, Précis de Droit International Privé, I (Paris: Librairie Dalloz, 1947), 273.

${ }^{36}$ A. Ferrer Correia, Lições de Direito Internacional Privado (Coimbra: Almedina, 2000), 422.

${ }^{37}$ See, on these two situations, Ph. Francescakis, in Répertoire de Droit International, Tome II, ed. Ph. Francescakis (Paris: Jurisprudence Génerale Dalloz, 1969), 54-62.
} 
purpose of fraus legis is to obtain an act or decision or to create a situation that aims to produce its effects in a State where a certain desired result is prohibited.

As a sanction, the aphorism fraus omnia corrumpit has been understood as depriving of legal effect the artificial situation created and determining the return to a non-defrauded state of things as means to avoid the perpetrator to avail himself of his fraudulent behaviour. However, the feigned means used, for instance the change of nationality, are not as such erased in the State of recognition, due to the lack of competence to adjudicate the validity of a foreign act. Indeed, through the institute of recognition only the effects of a foreign act are acknowledged, and not overruled or set aside the original act as such.

This general theory may also be applied in other fields where different legal orders interact, such as international administrative law, and where fraus legis represents an indirect way to reinforce trust between public authorities and to preserve untouched the remaining authority of the forum within recognition procedures. And that is why Alexandre sees this veracity requirement as the most powerful and justified curb to recognition of foreign decisions. ${ }^{38}$

\subsection{Fraus legis within the European Union}

In the midst of integration and strict cooperation arrangements, one might be led to believe, similarly to what occurs within the same legal order, that the relevance of fraus legis would be significantly reduced, given the strong mutual trust between State authorities and equivalence between legislations.

And in some situations this has been the case. One of the influences of European Union law (and the case law of its Court) has been argued to be the limitation of effects of the fraus legis doctrine, mainly in contract and company law. In fact, conducts that would once have been considered abnormal or insidious correspond now to a certain and admissible interpretation of fundamental principles and European Union freedoms. ${ }^{39}$ And, as such, avoidance of law does not tantamount to evasion of law.

\footnotetext{
${ }^{38}$ Danièle Alexandre, Les Pouvoirs du Juge de L'Exequatur (Paris: Librairie Générale de Droit et de Jurisprudence, 1970), 319.

${ }^{39}$ See, among others, Rui Manuel Moura Ramos, "O Tribunal de Justiça das Comunidades Europeias e a teoria geral do direito internacional privado: desenvolvimentos recentes”, in Estudos
} 
Plus, there are voices that, analysing the lack of references to fraus legis in European Union law instruments, believe that it should not include a general prohibition of fraud, since evasion of law could be properly fought by other means, "especially through use of flexible connecting factors, exception clauses and limitation of choice-of-law rules". ${ }^{40}$

This has not been, however, neither a generalised position, ${ }^{41}$ nor a preponderant one within every playing field of European Union law, mostly in what regards recognition of transnational acts. Indeed, the positions of those who consider fraus legis to be irrelevant ${ }^{42}$ do not resist the accumulation of legislative and jurisprudential developments.

As an example of the first, Directive 2013/55/EU of the European Parliament and of the Council of 20 November 2013 amending Directive 2005/36/EC on the recognition of professional qualifications and Regulation (EU) No. 1024/2012 on administrative cooperation through the Internal Market Information System establishes an alert mechanism according to which the competent authorities of a Member State shall, at the latest within three days from the date of adoption of a court decision, inform the competent authorities of all other Member States, by way of alert via IMI, about the identity of professionals who have applied for the recognition of a qualification under this Directive and who have subsequently been found by courts to have used falsified evidence of professional qualifications in this context [article 56a)].

This mechanism shows that the assertion and proof of fraud in the State of origin and, as a consequence, the termination of effects of a certain act

em Homenagem à Professora Doutora Isabel de Magalhães Collaço, Vol. I, ed. Rui Manuel de Moura Ramos, et al. (Coimbra: Almedina, 2002), 455-460.

${ }^{40}$ Kurt Siehr, "Fraude à la loi and European private international law", in Essays in Honour of Michel Bogdan (Lund: Juristförlaget, 2013), 538. Andreas Köhler, "General private international law institutes in the EU Succession Regulation - some remarks", Anali Pravnog Fakulteta Univerziteta u Zenici 18 (2016): 189, also argues that in the recent Successions Regulation the scope of application for fraus legis is, at best, very small and in any case limited to extreme exceptional circumstances. ${ }^{41}$ Analysing case law examples, Spyridon Vrellis [“'Abus' et 'fraude' dans la jurisprudence de la Cour de Justice des Communautés Européenes", in Vers de Nouveaux Équilibres entre Ordres Juridiques - Liber Amicorum Hélène Gaudemet-Tallon (Paris: Dalloz, 2008), 646] and Annekatrien Lenaerts ["The role of the principle frau omnia corrumpit in the European Union: A possible evolution towards a general principle of law?", Yearbook of European Law 32, 1 (2013): 484-485], considers that the European Court of Justice tends towards the consideration of the principle fraus omnia corrumpit as a (corrective and autonomous) general principle of European Union law, although it still lacks consistent application in individual cases.

${ }^{42}$ Such as Matteo Gnes, "General introduction: Towards an administration without frontiers migration opportunities in Europe”, European Review of Public Law 21, 1 (2009): 42. 
might also produce effects in the States of destination. However, this outcome is usually not automatic, for three main reasons: i) the effects of a recognised act are also a product of the process of recognition; therefore, there is a relative autonomy between both legal situations, the one in the State of origin and the one in the State of destination; ii) drawing effects from an unfavourable decision taken by the State of origin will mean the recognition of an adverse act (one that reverses a previous favourable act), which is so far only exceptionally admitted; and iii) legal certainty advises that both revocation and modification of a recognised act are explicitly adopted.

Thus, between two opposite ends - strict obedience to or concrete irrelevance of a decision of the State of origin which has considered a conduct to be fraudulent - it is up to the State of destination to prudentially analyse and ponder the causes that have led to that decision and the effects thereof. ${ }^{43}$

Even in the cases where there should be an automatic repercussion of a foreign decision in the State of recognition, such as in the driving licences field, ${ }^{44}$ there is an area where evasion of law is relevant (as debated in the case law of the European Court of Justice), since it is still up to the State of destination to draw effects from the withdrawal decision, according to the specificity of each situation and the need to ensure legal certainty and the protection of legitimate expectations.

Also the European Court of Justice has long admitted - though not imposed -that Member States, both from the State of origin and the State

\footnotetext{
${ }^{43}$ On the opposite, when authorities of the State of origin explicitly set aside the existence of fraud, the State of recognition is bond to that appraisal, except in the light of substantial new proof which contradicts the previous findings [cf. Miguel Prata Roque, A Dimensão Transnacional do Direito Administrativo - Uma visão cosmopolita das situações jurídico-administrativas (Lisboa: AAFDL, 2014), p. 1243, and Daniel Tan, "Enforcement of foreign judgments - should fraud unravel all? Hong Pian Tee v. Les Placements Germain Gauthier", Singapore Journal of International \& Comparative Law, 4 (2002): 1052-1053].

${ }^{44}$ According to article 11, no. 4 of Directive 2006/126/EC of the European Parliament and of the Council of 20 December 2006 on driving licences (Recast), a Member State shall refuse to issue a driving licence to an applicant whose driving licence is restricted, suspended or withdrawn in another Member State or to recognise a driving licence issued by another Member State to a person whose driving licence is restricted, suspended or withdrawn in the former State's territory. An automatism that was previously defended by Ulrich Berz, "Das EU-Übereinkommen über den Entzug der Fahrerlaubnis", NVwZ - Neue Zeitschrift für Verwaltungsrecht (1986); p. 147 and Michael Brenner, "Verfassungsfragen der Europäisierung des Führerscheinentzuges", DVBl. - Das Deutsche Verwaltungsblatt (1999): p. 884.
} 
of destination, deny effects to transnational acts whenever they were obtained in fraud to European Union requirements. ${ }^{45}$

This possibility of refusal requires the fulfilment of an objective element (the deceptive disregard of the finality prescribed by the European Union rule) and of a subjective element (the will to obtain an undue advantage by creating illusory conditions for such result), ${ }^{46}$ which imposes a more structured approach to fraudulent behaviour. Fraud goes therefore beyond discovering, by means of interpretation, a "hidden" violation of law, since it implies a specific factual animus or intention, precisely the one that questions the authority of European law. ${ }^{47}$

In general, in case C-109/01, ${ }^{48}$ the European Court of Justice took the opinion that free movement rights should not be extended to the nationals of a Member State and the nationals of a non-Member State who had entered into a marriage of convenience in order to circumvent the provisions relating to entry and residence of nationals of non-Member States; and in well-known case C-135/08, ${ }^{49}$ the same Court admitted that it is not contrary to European Union law for a Member State to withdraw the nationality of that State acquired by naturalisation when it was obtained by deception, on the condition that the decision of withdrawal observed

\footnotetext{
${ }^{45}$ See, among others, Robin Morris, "European citizenship: Cross-border relevance, deliberate fraud and proportionate responses to potential statelessness", European Public Law 17, 3 (2011): 417-435.

${ }^{46}$ Annekatrien Lenaerts ["The role of the principle frau omnia corrumpit in the European Union: A possible evolution towards a general principle of law?", Yearbook of European Law 32, 1 (2013): 490 and 489, defends that malicious intent (intention to obtain a wrongful profit and to harm another person) is a necessary element beyond the violation of the objective of a Union Rule. Cf., in case law, Judgment of 30 September 1997, Faik Günaydin, Hatice Günaydin, Günes Günaydin and Seda Günaydin v. Freistaat Bayern, C-36/96, EU:C:1997:445: and Judgement of 12 September 2006, Cadbury Schweppes plc, Cadbury Schweppes Overseas Ltd v. Commissioners of Inland Revenue, C-196/04, EU:C:2006:544. The first considers relevant the "sole intention of improperly obtaining work and residence permits" and the second "wholly artificial arrangements intended to escape the national tax normally payable".

${ }^{47}$ About the terms of coexistence between the objective or material and the subjective or psychological elements of fraus legis, cf. Alexandre Rey Colaço de Castro Freire, "A fraude à lei no direito internacional privado", Revista da Ordem dos Advogados (1954 - 1955 - 1956): 88-92.

${ }^{48}$ Judgment of 23 September 2003, Secretary of State for the Home Department and Hacene Akrich, C-109/01, EU:C:2003:491.

${ }^{49}$ Judgment of 2 March 2010, Janko Rottmann v. Freistaat Bayern, C-135/08, EU:C:2010:104.
} 
the principle of proportionality, mainly in what regards its influence in the European citizenship status. ${ }^{50}$

Previously, in case 292/86, in the realm of recognition, the Court had already held that a lawyer established in a Member State who wished to provide services in another Member-State where he had been barred from access to the legal profession for reasons relating to his dignity, good reputation and integrity, could not rely on the then applicable Directive $77 / 249 .{ }^{51}$

Similar to this situation, others exist where the European Court of Justice has barred the interested party from using foreign certifications or homologations which were not based on a real verification of qualifications or experience, since this might allow access to professions or activities without the required title. In these cases, Member States can overlook a manifestly inaccurate certification that is of genuine relevance to the exercise of the activity at stake in order to prevent recognition to be used to circumvent European Union demands. ${ }^{52}$

But it is within the driving licences field that the issue of non-recognition due to the occurrence of fraus legis has been discussed and developed as a way to promote the shared objective of road safety and to avoid driving licences tourism..$^{53}$

\footnotetext{
${ }^{50}$ Also before in its Judgment of 5 June 1997, Suat Kol v. Land Berlin, C-285/95, EU:C:1997:280, the Court had decided that "article 6(1) of Decision No. 1/80 of 19 September 1980 on the development of the Association, adopted by the Council of Association established by the Association Agreement between the European Economic Community and Turkey, is to be interpreted as meaning that a Turkish worker does not satisfy the condition of having been in legal employment, within the meaning of that provision, in the host Member State, where he has been employed there under a residence permit which was issued to him only as a result of fraudulent conduct in respect of which he has been convicted".

${ }^{51}$ Judgment of 19 January 1988, Claude Gullung v. Conseils de l'Ordre des Avocats du Barreau de Colmar et de Saverne, 292/86, EU:C:1988:15.

${ }^{52}$ In the words of Barbara Gagliardi, "Libertà di circolazione dei lavoratori, concorsi pubblici e mutuo riconoscimento dei diplomi”, Foro Amministrativo 9, 4 (2010): 748, if this was admissible, a "game of mirrors" would occur that would lead to an inadmissible second-degree recognition. See, for instance, Judgment of 27 September 1989, C. C. van de Bijl v Staatssecretaris van Economische Zaken, 130/88, EU:C:1989:349; Judgment of 2 May 1996, Brennet AG v. Vittorio Paletta, C-206/94, EU:C:1996:182; and Judgment of 9 January 2009, Consiglio Nazionale degli Ingegneri v. Ministero della Giustizia, Marco Cavallera, C-311/06, EU:C:2009:37.

${ }^{53}$ Markus Möstl, "Preconditions and limits of mutual recognition", Common Market Law Review 47 (2010): 431.
} 
Initially, in case C-476/01, ${ }^{54}$ the European Court of Justice precluded a Member State from refusing to recognise a driving licence issued by another Member State on the grounds that the holder had, at the moment of its emission, residence in the State of recognition and not in the issuing State, due to the circumstance that the exclusive competence belonged to the latter. ${ }^{55}$ It continued by stating that when a host Member State has good reason to doubt the validity of one or more licences issued by another Member State, the only action that might be taken is to inform the latter in order for it to take the appropriate measures to preserve the effect of European Union law.

The European Court of Justice decision in joined Cases C-329/06 e C-343/06 was, however, more open to the possibility of fraus legis acting as an exception to recognition. ${ }^{56}$ In this judgment, the Court textually stated

\footnotetext{
${ }^{54}$ Judgment of 29 April 2004, Felix Kapper, C-476/01, EU:C:2004:261. This judgement also precluded a Member State from refusing to recognise the validity of a driving licence issued by another Member State on the grounds that its holder had, in the first Member State, been subject to a measure withdrawing or cancelling the driving licence where a temporary ban on obtaining a new licence has expired before the date of issue of the licence in the second Member State. This in order to avoid the infringement of the principle of mutual recognition through the establishment of indefinite bans on other Member States licences. Filling the gaps of this part of that judicial decision, see the European Court of Justice Judgment of 20 November 2008, Frank Weber, C-1/07, EU:C:2008:640, and, more recently, Judgment of 21 May 2015, Andreas Wittmann, C-339/14, EU:C:2015:333.

${ }^{55}$ See also Judgment of 10 July 2003, Commission of the European Communities v. Kingdom of the Netherlands, Case C-246/00, EU:C:2003:398, and the Order of the Court, José António da Silva Carvalho, Case C-408/02, EU:C:2003:672, according to which the possession of a driving licence issued by one Member State has to be regarded as constituting proof that the holder fulfilled the legal conditions (such as residence) to be awarded one.

It is well known that harmonisation of competence rules is one of the measures that avoid fraud and reinforce mutual trust between Member States [Vassilis Hatzopoulos, "Le principe de reconnaissance mutuelle dans la libre prestation des services", Cahiers de Droit Européen 46, 1-2 (2010): 83]. However, fraud regarding the connecting element of residence will continue to be relevant even in the case of unification of competence rules, due to the difficulty of determining such criterion in particular cases. Vide Judgment of 25 June 2015, VAS "Ceḷ satiksmes drošǐbas direkcija", Latvijas Republikas Satiksmes ministrija v. Kaspars Nimanis, C-664/13, EU:C:2015:417, that precludes legislation of a Member State under which the only way in which a person who applies for the issue or renewal of a driving licence in that Member State can prove that they satisfy the condition of "normal residence" is to establish that they have a declared place of residence in the territory of the Member State concerned.

${ }^{56}$ Judgment of 26 June 2008, Arthur Wiedemann v. Land Baden-Württemberg and Peter Funk v. Stadt Chemnitz, joined Cases C-329/06 and C-343/06, EU:C:2008:366. This decision received confirmation in Judgment of 19 May 2011, Mathilde Grasser v. Freistaat Bayern, C-184/10, EU:C:2011:324, and in Judgment of 13 October 2011, Leo Apelt, C-224/10, EU:C:2011:655.
} 
that it is not contrary for a Member State to refuse to recognise (or to suspend) in its territory the right to drive stemming from a driving licence subsequently issued by another Member State "if it is established, on the basis of entries appearing in the driving licence itself or of other incontestable information supplied by the Member State of issue, that when that licence was issued its holder, who had been the object, in the territory of the first Member State, of a measure withdrawing an earlier licence, was not normally resident in the territory of the Member State of issue".

From this decision, two guiding lines in appraising fraus legis situations can be deduced: i) the manipulation should have rested upon essential European Union law criteria, in the case, an explicit competence rule based on a residence requirement, and; ii) the veracity review should be made according to undisputable elements available to the Member State of issue $e^{57}$ and not according to information offered afterwards. The circumscribed nature of these requirements is understandable since they open the gates to a restriction on mutual recognition that should always be interpreted strictly and only applied exceptionally.

Nevertheless, they demonstrate that, even in situations of automatic recognition, fraus legis can be relevant, as long as there is an actual and important interest of the Member State of destination to uphold the authority of European Union law and to promote its effectiveness.

In situations of conditional recognition, Member States of destination have a broader leeway to refuse recognition based on fraus legis. ${ }^{58}$ Not only is the proof of evasion of law facilitated since there is a formal moment where the Member State of destination intervenes, allowing for an added collection of information, but it is also possible to take into consideration all aspects, public and private, that might ex ante oppose the production of effects of the foreign act.

A fraudulent invocation of European Union law that would enable a positive result contrary to community objectives is therefore subject to

\footnotetext{
${ }^{57}$ For this purpose, it should be irrelevant whether such information was known indirectly through a communication made by third parties (Judgment of 1 March 2012, Baris Akyüz, C-467/10, EU:C:2012:112). In any case, that information must be undisputed and issued by the State of origin (Order of 9 July 2009, Kurt Wierer v. Land Baden-Württemberg, C-445/08, EU:C:2009:443).

${ }^{58}$ We agree with Daniel Tan, "Enforcement of foreign judgments - should fraud unravel all? Hong Pian Tee v. Les Placements Germain Gauthier", Singapore Journal of International \& Comparative Law 4 (2002): 1047, who considers that in some cases the country of origin might not be the best qualified to decide whether a judgment or act was obtained by fraud, for instance if the allegation was that the fraud consisted of the bribery of a judicial officer.
} 
censorship and sanctioning, ${ }^{59}$ depending on the result of a prudent and reasonable composition of interests. ${ }^{60}$

In fact, for fraus legis doctrine to operate it is necessary that the European Union objective that is manipulated is imperative ${ }^{61}$ and that this manipulation is not justified by other fundamental principles and freedoms of this field of law. Also irrefutable proof of fraud must be provided, and if it is the case, Member State authorities are legitimised to further reality over appearance, ${ }^{62}$ consequently introducing exceptions to recognition.

\section{Conclusion}

Fraus legis doctrine has traditionally played a relevant role in the international realm and, despite the fact that its importance within European Union law has not always been clear, it has gained a renewed vitality in recent years, mostly within recognition procedures.

These procedures involve a possibility of control of recognition criteria, among which veracity plays a prominent role. Indeed, effectiveness of European Union law should not be understood as a formal concept, but as one that must be anchored in real substantive requirements, not merely in apparent or even untrue creations.

Refusing to recognise effects to situations and acts constituted in fraudem legis is thus a valuable tool for prudently guaranteeing the respect for essential European Union law rules and promoting rooted mutual trust between Member States.

\footnotetext{
${ }^{59}$ Given the fact that the sanction is linked to the manipulation of European Union rules - rules that every Member State must uphold -, the discussion about sanctioning fraus legis to foreign legislation or only to the lex fori loses its importance. For arguments for and against this sanctioning, see Bernard Audit, La Fraude à la Loi (Paris: Dalloz, 1974), 164-213.

${ }^{60}$ As aforesaid by Alexandre Ligeropoulo, "La defensa de derecho contra el fraude", Revista de Derecho Privado XVII, 196 (1930): 25.

${ }^{61}$ Viewing fraus legis as a subsidiary sanction of imperative rules, cf. J. P. Niboyet, "La fraude à la loi en droit international privé", Revue de Droit International et de Legislation Comparé (1926): 492. J. J. Fawcett, "Evasion of law and mandatory rules in private international law", Cambridge Law Journal 49, 1 (1990): 56-57, sees evasion of law as objectionable in cases where there is unfairness and in cases where the national interest is affected, thus pointing out the European concept of mandatory rules.

${ }^{62}$ Henri Batiffol and Paul Lagarde, Droit International Privé, $7^{\text {th }}$ ed., Tome I (Paris: L.G.D.J., 1981), 430.
} 


\section{Bibliography}

Alexandre, Danièle. Les Pouvoirs du Juge de L'Exequatur. Paris: Librairie Générale de Droit et de Jurisprudence, 1970.

Annekatrien Lenaerts. "The role of the principle frau omnia corrumpit in the European

Union: A possible evolution towards a general principle of law?”. Yearbook of European Law 32, 1 (2013): 460-498.

Arminjon, P. Précis de Droit International Privé, I. Paris: Librairie Dalloz, 1947.

Armstrong, Kenneth A. "Mutual recognition". In The Law of the Single European Market - Unpacking the Premisses, edited by Catherine Barnard and Joanne Scott, 225-267. Oxford: Hart Publishing, 2002.

Audit, Bernard. La Fraude à la Loi. Paris: Dalloz, 1974.

Azcárraga Monzonís, Carmen. "New developments in the scope of the circulation of public documents in the European Union". Zeitschrift für Zivilprozess International - Jahrbuch des Internationalen Zivilprozessrechts 18 (2013): 245-279.

Bassi, Nicola. Mutuo Riconoscimento e Tutela Giurisdizionale - La Circolazione degli Effeti del Provvedimento Amministrativo Straniero fra Diritto Europeo e Protezione degli Interessi del Terzo. Milano: Giuffrè Editore, 2008.

Batiffol, Henri and Paul Lagarde. Droit International Privé. $7^{\text {th }}$ ed., Tome I. Paris: L.G.D.J., 1981.

Berz, Ulrich. "Das EU-Übereinkommen über den Entzug der Fahrerlaubnis”. NVwZ Neue Zeitschrift für Verwaltungsrecht (1986): 145-147.

Brenner, Michael. "Verfassungsfragen der Europäisierung des Führerscheinentzuges”. DVBl. - Das Deutsche Verwaltungsblatt (1999): 877-884.

Biscottini, Giuseppe. Diritto Amministrativo Internazionale - Tomo Primo/ La Rilevanza degli Atti Amministrativi Stranieri. Padova: CEDAM, 1964.

Burbaum, Stefan. Rechtsschutz gegen transnationales Verwaltungshandeln. BadenBaden: Nomos Verlagsgesellschaft, 2003.

Bureau, Dominique and Horatia Muir Watt. Droit International Privé, Tome I - Partie Générale. $3^{\text {rd }}$ ed. Paris: Presses Universitaires de France, 2014.

Correia, A. Ferrer. Lições de Direito Internacional Privado. Coimbra: Almedina, 2000. Davies, Gareth. "Is mutual recognition an alternative to harmonization? Lessons on trade and tolerance of diversity from the EU'. In Regional Trade Agreements and the WTO Legal System, edited by Lorand Bartels and Federico Ortino, 265-280. Oxford: Oxford University Law, 2006.

Fawcett, J. J. "Evasion of law and mandatory rules in private international law". Cambridge Law Journal 49, 1 (1990): 44-62.

Fedozzi, Prosper. "De l'efficacité extraterritoriale des lois et des actes de droit public". Recueil des Cours. Volume 27 - II (1929): 145-239. 
Francescakis, $\mathrm{Ph}$. (ed.). Répertoire de Droit International. Tome II. Paris: Jurisprudence Génerale Dalloz, 1969.

Freire, Alexandre Rey Colaço de Castro. "A fraude à lei no direito internacional privado". Revista da Ordem dos Advogados (1954 - 1955 - 1956): 68-98.

Freitas, José Lebre de. "A fraude à lei na provocação da competência do tribunal estrangeiro". Revista da Faculdade de Direito da Universidade de Lisboa XXXIX, 1 (1998): 7-15.

Gagliardi, Barbara. "Libertà di circolazione dei lavoratori, concorsi pubblici e mutuo riconoscimento dei diplomi”. Foro Amministrativo 9, 4 (2010): 735-750.

Gautier, Pierre-Yves. "La contrariété à l'ordre public d'une décision étrangère, échec à sa reconnaissance ou son exequatur". In Vers de Nouveaux Équilibres entre Ordres Juridiques - Liber Amicorum Hélène Gaudemet-Tallon, 437-445. Paris: Dalloz, 2008.

Gnes, Matteo. "General introduction: Towards an administration without frontiers migration opportunities in Europe”. European Review of Public Law 21, 1 (2009): 35-62.

Götz, Volkmar. "Der Grundsatz der gegenseitigen Anerkennung im europäischen Binnenmarkt”. In Liber Amicorum Günther Jaenicke - Zum 85. Geburtstag, edited by Volkmar Götz, Peter Selmer and Rüdiger Wolfrum, 763-791. Berlin: Springer, 1998.

Guyon-Renard, Isabelle. "La fraude en matière de l'État civil dans les États Membres de la CIEC". Revue Critique de Droit International Privé 85, 3 (1996): 541-556.

Hatzopoulos, Vassilis. "Le principe de reconnaissance mutuelle dans la libre prestation de services". Cahiers de Droit Européen 46, 1-2 (2010): 47-93.

Kegel, Gerhard and Klaus Schurig. Internationales Privatrecht - Ein Studienbuch. $9^{\text {th }}$ ed. München: Verlag C.H. Beck, 2004.

Köhler, Andreas. "General private international law institutes in the EU Succession Regulation - some remarks". Anali Pravnog Fakulteta Univerziteta u Zenici 18 (2016): 169-191.

Ligeropoulo, Alexandre. "La defensa de derecho contra el fraude". Revista de Derecho Privado XVII, 196 (1930): 1-25.

Lopes, Dulce. Eficácia, Reconhecimento e Execução de Actos Administrativos Estrangeiros. Coimbra: Almedina, 2018.

Lucia, Luca de. "Administrative pluralism, horizontal cooperation and transnational administrative acts". Review of European Administrative Law 5, 2 (2012): 17-45.

Machado, João Baptista. Lições de Direito Internacional Privado. $3^{\text {rd }}$ ed. Coimbra: Almedina, 1995.

Mansel, Heinz-Peter. “Anerkennung als Grundprinzip des Europäischen Rechtsraums Zur Herausbildung eines europäischen Anerkennungs-Kollisionsrechts: Anerkennung statt Verweisung als neues Strukturprinzip des Europäischen internationalen 
Privatrechts?". Rabels Zeitschrift für ausländisches und internationales Privatrecht 70, 4 (2006): 654-731.

Mayer, Pierre. "Les méthodes de la reconnaissance en droit international privé". In Le Droit International Privé: Esprit et Méthodes - Mélanges en l'Honneur de Paul Lagarde, 547-573. Paris: Dalloz, 2005.

Meng, Werner. "Recognition of foreign legislative and administrative acts". In Encyclopaedia of Public International Law, Vol. IV, edited by Rudolf Bernhardt, 50-54. North-Holland: Elsevier, 1992.

Morris, Robin. "European citizenship: Cross-border relevance, deliberate fraud and proportionate responses to potential statelessness". European Public Law 17, 3 (2011): 417-435.

Möstl, Markus. "Preconditions and limits of mutual recognition". Common Market Law Review 47 (2010): 405-436.

Neumeyer, Karl. Internationales Verwaltungsrecht - Allgemeiner Teil, Vol. IV. Zürich; Leipzig: Verlag für Recht und Gesellschaft AG, 1936.

Niboyet, J. P. Cours de Droit International Privé. Paris: Librairie du Recueil Sirey, 1949. Niboyet, J. P. "La fraude à la loi en droit international privé”. Revue de Droit International et de Législation Comparé (1926): 485-508.

Nicolaïdis, Kalypso. "Globalization with human faces: Managed mutual recognition and the free movement of professionals". In The Principle of Mutual Recognition in the European Integration Process, edited by Fiorella Kostoris and Padoa Schioppa, 129-189. Hampshire: Palgrave Macmillan, 2005.

Nicolaidis, Kalypso and Gregory Shaffer. "Transnational mutual recognition regimes: Governance without global government". Law and Contemporary Problems 68, Summer-Autumn (2005): 263-371.

Otero, Paulo. "Normas administrativas de conflitos: As situações jurídico-administrativas transnacionais". In Estudos em Memória do Professor Doutor António Marques dos Santos, Vol. II, edited by Dário Moura Vicente, Luís de Lima Pinheiro and Jorge Miranda, 781-790. Coimbra: Almedina, 2005.

Pamboukis, Charalambos. L'Acte Public Étranger em Droit International Privé. Paris: L.G.D.J., 1993.

Patrão, Afonso. Autonomia Conflitual na Hipoteca e Reforço da Cooperação Internacional: Removendo Obstáculos ao Mercado Europeu de Garantias Imobiliárias. Lisboa: Livros Horizonte, 2017.

Piçarra, Nuno. "A liberdade de circulação dos advogados na União Europeia - Da metamorfose da regra do tratamento nacional à extensão a nacionais de países terceiros". In Estudos em Homenagem ao Prof. Doutor Sérvulo Correia, Vol. IV, edited by Jorge Miranda, 707-748. Coimbra: Coimbra Editora, 2010. 
Pinheiro, Luís de Lima. "Reconhecimento autónomo de decisões estrangeiras e controlo do direito aplicável". In Estudos de Direito Internacional Privado - Direito de Conflitos, Competência Internacional e Reconhecimento de Decisões Estrangeiras, 435-464. Coimbra: Almedina, 2006.

Ramos, Rui Manuel Moura. "O Tribunal de Justiça das Comunidades Europeias e a teoria geral do direito internacional privado: Desenvolvimentos recentes". In Estudos em homenagem à Professora Doutora Isabel de Magalhães Collaço, Vol. I, edited by Rui Manuel de Moura Ramos, 431-467. Coimbra: Almedina, 2002.

Raschauer, Bernhard. “Transnationale Verwaltungsakte”. In Demokratie und sozialer Rechtsstaat in Europa: Festschrift für Theo Öhlinger, edited by Stefan Hammer, Alexander Somek, Manfred Stelzer, and Barbara Weichselbaum, 661-684. Wien: WUV Universitätsverlag, 2004.

Röhl, Hans Christian. "Conformity assessment in European product safety law". In The European Composite Administration, edited by Oswald Jansen and Bettina Schöndorf-Haubold, 201-226.Cambridge: Intersentia, 2011.

Roque, Miguel Prata. A Dimensão Transnacional do Direito Administrativo - Uma Visão Cosmopolita das Situações Jurídico-Administrativas. Lisboa: AAFDL, 2014.

Schmidt-Aßman, Eberhard. "Internationalisation of administrative law: Actors, fields and techniques of internationalisation - impact of international law on national administrative law”. Revue Européenne de Droit Public 18, 1 (2006): 249-268.

Schmidt-Aßmann, Eberhard. "Verfassungsprinzipien für den Verwaltungsverbund". In Grundlagen des Verwaltungsrechts. $2^{\text {nd }}$ ed. Vol. I, edited by Hoffmann-Riem, Schmidt-Aßmann, Voßkuhle, 261-340. München: Verlag C. H. Beck, 2012.

Siehr, Kurt. "Fraude à la loi and European private international law". Essays in Honour of Michel Bogdan, 521-538. Lund: Juristförlaget, 2013.

Sinopoli, Laurence. "Une épreuve pour les droits de l'Homme - de l'universel postulé à la mondialisation réalisée?". In Justices et Droit du Procès - Du Légalisme Procédural à l'Humanisme Processuel - Mélanges en l'Honneur de Serge Guinchard, 369-379. Paris: Dalloz, 2010.

Tan, Daniel. "Enforcement of foreign judgments - should fraud unravel all? Hong Pian Tee v. Les Placements Germain Gauthier". Singapore Journal of International \& Comparative Law 4 (2002): 1043-1057.

Tietje, Christian. “Internationalisiertes Verwaltungshandeln”. Rechtstheorie 39 (2008): 255-276.

Vicente, Dário Moura. "Liberdades comunitárias e direito internacional privado". Revista da Ordem dos Advogados 69 (2009): 729-813. 
Vogel, Klaus. Der räumliche Anwendungsbereich der Verwaltungsrechtsnorm - Eine Untersuchung über die Grundfragen des sog. internationalen Verwaltungs- und Steuerrechts. Frankfurt am Main: Alfred Metzner Verlag, 1965.

Von Stein, Lorenz. "Einige Bemerkungen über das internationale Verwaltungsrecht". Jahrbuch für Gesetzgebung, Verwaltung und Volkswirtschaft im Deutschen Reich 6 (1882): 395-442.

Vrellis, Spyridon. “'Abus' et 'fraude' dans la jurisprudence de la Cour de Justice des Communautés Européenes”. In Vers de Nouveaux Équilibres entre Ordres Juridiques - Liber Amicorum Hélène Gaudemet-Tallon, 634-646. Paris: Dalloz, 2008.

Weiß, Käte. Die Anerkennung ausländischer Verwaltungsakte. Göttingen: Buchdruckerei W. Flentje, 1932.

Wenander, Henrick. "Recognition of foreign administrative decisions - Balancing international cooperation, national self-determination, and individual rights". Zeitschrift für ausländisches öffentliches Recht und Völkerrecht 71 (2011): 755-785.

Wojtyczek, Krysztof. “'Louverture de l'ordre juridique de l'État aux actes de puissance publique étrangers (l'exemple des instruments de l'Union Européenne en matière d'immigration)". European Review of Public Law 21, 1 (2009): 105-134. 